DOI: https://doi.org/10.47405/mjssh.v5i10.504

\begin{tabular}{|c|c|}
\hline 4 & Malaysian Journal of Social Sciences and Humanities (MJSSH) \\
\hline $\begin{array}{l}\text { Malaysian Journal of } \\
\text { Social sciences and }\end{array}$ & Volume 5, Issue 10, October 2020 \\
\hline (MJ-SSH) & e-ISSN : 2504-8562 \\
\hline & $\begin{array}{l}\text { Journal home page: } \\
\text { www.msocialsciences.com }\end{array}$ \\
\hline
\end{tabular}

\title{
Analisis Rasch bagi Ujian Pemikiran Sains Keusahawanan dalam Pendidikan STEM Sekolah Rendah
}

\author{
Jamilah Ahmad1, Siew Nyet Moi @ Sopiah Abdullah' \\ 1 Universiti Malaysia Sabah (UMS)
}

Correspondence: Jamilah Ahmad (jamilahahmad99@gmail.com)

\begin{abstract}
Abstrak
Instrumen Ujian Pemikiran Sains Keusahawanan (UPSK) telah dibina bertujuan mengukur pemikiran sains keusahawanan dalam Pendidikan STEM sekolah rendah. Kajian ini bertujuan mennentukan kualiti instrumen UPSK melalui kesahan dan kebolehpercayaan instrumen UPSK melalui Model Pengukuran Rasch. UPSK adalah rangkuman soalan terbuka yang terdiri daripada sepuluh item dengan lima pecahan konstruk iaitu: pemerhatian, idea baharu, inovasi, kreativiti dan nilai. Sampel terdiri daripada 166 orang pelajar yang berusia 10 hingga 11 tahun dari sekolah-sekolah bandar di daerah Tawau, Sabah. Hasil analisis kesahan mendapati polariti item melalui nilai PTMEA-Corr menunjukkan bahawa kesemua 10 item berada $>0.00(+)$. Melalui analisis kesesuaian item, semua item masih dikekalkan kerana memenuhi syarat dalam salah satu julat outfit MNSQ, Outfit ZSTD dan PTMEACorr. Dalam analisis komponen utama (PCA), nilai Raw Variance Explained by Measures 66.8\% (cemerlang) dan nilai Unexplained variance dalam kontras pertama di bawah $15 \%$ menunjukkan bahawa instrumen mempunyai keekadimensian yang kuat dan mempunyai kesahan konstruk yang tinggi. Kebolehpercayaan Cronbach Alpha (KR-20) menunjukkan nilai 0.91 (sangat tinggi), kebolehpercayaan item 0.98 (cemerlang) dan responden 0.89 (baik) dengan nilai pengasingan item 7.97 dan responden 2.83. Kesimpulannya, UPSK mempunyai kesahan yang baik dan kebolehpercayaan yang tinggi dalam mengukur pemikiran sains keusahawanan dalam kalangan pelajar tahun lima di sekolah rendah di Sabah.
\end{abstract}

Kata kunci: kesahan, kebolehpercayaan, pemikiran sains keusahawanan, Model Pengukuran Rasch

\section{Rasch Analysis of Entrepreneurial Science Thinking Test in Primary STEM}

\begin{abstract}
The Entrepreneurship Science Thinking Test (ESTT) Instrument was developed to measure entrepreneurial science thinking in primary school STEM Education. This study means to decide the the quality of ESTT instruments through the validity and reliability of ESTT instruments using the Rasch Measurement Model. ESTT comprises of ten open ended questions with five constructs namely: observation, new ideas, innovation, creativity and value. The sample consisted of 166 students aged 10 to 11 years from urban schools in Tawau district, Sabah. Validity analysis found that the polarity of the items through the PTMEA-Corr value indicated that all ten items were $>0.00(+)$. Through item suitability analysis, all items are still retained as they meet the requirements in one of the MNSQ, Outfit ZSTD and PTMEA-Corr outfit ranges. In the Principal Components Analysis (PCA), the Raw Variance Explained by Measures, $66.8 \%$ (excellent) and the Unexplained variance value in the first contrast below $15 \%$ indicate that the instrument has a strong dimensionality and has high construct
\end{abstract}


validity. The reliability of Cronbach Alpha (KR-20) demonstrated a value of 0.91 (very high), item reliability of 0.98 (excellent) and respondent 0.89 (good) with an isolation value of item 7.97 and respondent 2.83. In conclusion, ESTT has good validity and high reliability in measuring entrepreneurial science thinking among year five students in primary schools in Sabah.

Keywords: validity, reliability, science entrepreneurial thinking, Rasch Measurement Model

\section{Pengenalan}

Dalam menghadapi revolusi Industri 4.0 yang kian rancak, negara perlu menyediakan modal insan yang berfikiran kritikal, mampu mencipta idea yang kreatif dan inovatif serta mempunyai nilai etika yang tinggi. Sehubungan dengan itu, pemikiran keusahawanan dilihat sebagai salah satu kemahiran penting dalam menghadapi dunia yang kian kompetetif (Bacigalupo et al., 2016; Nor Aishah Buang et al., 2009). Malah, wujud keperluan untuk menerapkan elemen keusahawanan dalam kurikulum pendidikan (Saavedra \& Opfer, 2012). Pemikiran keusahawanan bukanlah satu kemahiran yang perlu dikuasai untuk menjadi usahawan semata-mata, tetapi ia adalah satu kemahiran insaniah yang penting dalam mengukuhkan pembangunan kemanusiaan, memenuhi pasaran kerja dan meningkatkan persaingan (Bacigalupo et al., 2016). Pemikiran keusahawan ini sangat perlu dalam melahirkan pelajar yang dapat menguasai ciri dan etika keusahawanan, mengendalikan sumber sedia ada dengan baik dan menghadapi cabaran pada masa hadapan dengan cekap (Edwards-Schachter et al., 2015). Kemahiran ini akan membolehkan pelajar kita bersifat lebih kritikal, pemikir yang kreatif dan inovatif, efektif dalam berkomunikasi dan warga kerja yang beretika (Lekashvili, 2013).

Rentetan daripada keperluan pemikiran keusahawanan dalam pembelajaran, beberapa sarjana tempatan mula mengkaji keperluan pemikiran ini. Nor Aishah, Lilia, dan T. Subahan (2009) telah mencadangkan penggabungjalinan Kemahiran Proses Sains (KPS) dan pemikiran keusahawanan yang dikenali sebagai Pemikiran Sains Keusahawanan (PSK). Pemikiran ini mengintegrasikan konsep penyelesaian masalah dan elemen keusahawanan untuk melatih pelajar mencari idea-idea tuntas dalam menyelesaikan sesuatu masalah secara kreatif (Muhammad Syukri et al., 2013). Penerapan pemikiran sains keusahawanan perlu dimulakan dari peringkat rendah lagi bagi memastikan pengaplikasian ilmu sains berlandaskan pemikiran sains keusahawanan dapat dipupuk (Liu \& Zhi, 2010; Menzies, 2012). Selaras dengan itu, Ujian Pemikiran Sains Keusahawanan (UPSK) telah dibangunkan untuk mengukur pemikiran sains keusahawanan dalam kalangan pelajar Tahun Lima di sekolah rendah.

Kementerian Pendidikan Malaysia pernah cuba menerapkan elemen keusahawanan dalam kurikulum lama sebelum pelaksanaan Kurikulum Standard Sekolah Rendah dan Menengah. Sebelum ini, elemen keusahawanan pernah diterapkan dalam kurikulum sekolah, contohnya melalui mata pelajaran Kewangan dan Asas Keusahawanan yang ditawarkan kepada pelajar-pelajar aliran Sastera sahaja. Sunguhpun usaha ini telah dibuat, pelajar didapati kurang membudayakan elemen dan kemahiran keusahawanan ini dalam kehidupan mereka (Kementerian Pendidikan Malaysia, 2013).

Kini, keperluan global dan tuntutan semasa untuk menghadapi dunia yang semakin kompetetif sudah berubah. Timbul keperluan yang tinggi terhadap perlunya penerapan pemikiran keusahawanan ini dalam kurikulum agar pelajar yang dihasilkan berupaya untuk mencipta, berinovasi dan mempunyai nilai keusahawanan sekali gus dapat memenuhi kriteria modal insan yang diharapkan (Kementerian Pendidikan Malaysia, 2013). Pengintegrasian keusahawanan melalui pembelajaran STEM adalah salah satu langkah pragmatik bagi menggalakkan pelajar meminati STEM dan sekali gus belajar memasarkan idea (European Commission, 2011; Shepherd et al., 2015).

Sungguhpun PSK sudah mula dicanang dalam kurikulum Malaysia, pembangunan instrumen yang mengukur tahap pemikiran sains keusahawanan belum lagi meluas (Muhammad Syukri et al., 2013; Nor Aishah Buang et al., 2009). Instrumen yang pernah dibangunkan sebelum ini hanya mengukur kesediaan integrasi pemikiran sains keusahawanan guru (Zulfaka Ishak et al., 2014) dan pengetahuan pedagogi guru dalam mengajar pemikiran sains keusahawanan (Muhammad Syukri, Lilia Halim, 
Subahan Mohd. Meerah, 2013). Oleh itu, pengkaji membangunkan instrumen ini dan mengukur kesahan dan kebolehpercayaan bagi memastikan instrumen ini boleh digunakan di lapangan sebenar dan panduan kepada para pengkaji yang ingin mengkaji tentang pemikiran sains keusahawanan pelajar di sekolah rendah.

\section{Sorotan Literatur}

\section{Pendidikan STEM}

Pendidikan STEM (Sains, Teknologi, Kejuruteraan dan Matematik) mula dilaksanakan di Amerika Syarikat pada akhir abad ke-20 (Koehler et al., 2015). Pada ketika itu, kerajaan Amerika Syarikat mempersiapkan masyarakatnya untuk menceburi bidang STEM dan memasuki kerjaya yang berkaitan bidang STEM seperti saintis, jurutera, pakar matematik atau pakar teknologi (Dabney et al., 2012; Friedman, 2005; Sadler, Sonnert, Hazari, \& Tai, 2012; Wyss, Heulskamp, \& Siebert, 2012). Kini, pendidikan STEM sudah dilaksanakan di serata dunia lantaran keperluannya untuk memenuhi pasaran kerja dalam keempat-empat bidang ini (English, 2017; Kelley \& Knowles, 2016).

Pendidikan STEM membolehkan pelajar untuk mempelajari STEM dalam konteks sebenar dan mengembangkan literasi STEM pelajar agar dapat bersaing dalam era ekonomi baharu (Tsupros et al., 2009) dan dapat menghadapi cabaran kehidupan seharian yang berkaitan dengan bidang STEM (Bybee, 2013). Melalui pengintegrasian ilmu, nilai dan kemahiran dalam keempat-empat bidang ini, Pendidikan STEM dapat meyediakan medium pembelajaran yang komprehensif (Tseng et al., 2013). Terdapat juga kajian yang menunjukkan bahawa pendekatan Pendidikan STEM dapat meningkatkan literasi Sains dan kemahiran reka bentuk kejuruteraan (Afriana et al., 2016; Committee on STEM Education, 2018; Jin \& Bierma, 2013; Kennedy \& Odell, 2014; Kuenzi, 2011; McDonald, 2016; Zollman, 2012). Selain itu, pendidikan STEM juga berupaya memupuk minat pelajar terhadap sains dan membentuk keperibadian pelajar dengan ilmu dan kemahiran STEM yang kemprehensif (Committee on STEM Education, 2018; McDonald, 2016).

Laporan Pelan Pembangunan Pendidikan Malaysia 2013-2025 memberi penekanan kepada pelaksanaan STEM sebagai asas dalam penyediaan graduan STEM terlatih yang mencukupi bagi memenuhi pasaran kerja yang memacu ekonomi Malaysia. Kini, STEM di Malaysia sudah pun berada dalam akhir Gelombang Kedua. Maka, keperluan pelaksanaan pendidikan STEM di sekolah perlu dilaksanakan secara eksplisit bermula di peringkat rendah lagi bagi mencapai hasrat negara melahirkan modal insan berkemahiran STEM yang mampu menyelesaikan masalah sejagat, membuat keputusan dan mencipta untuk manfaat masyarakat akan datang.

\section{Pemikiran Sains Keusahawanan}

Istilah pemikiran keusahawanan sebenarnya lahir daripada konsep keusahawanan. Krueger (2007) menjelaskan bahawa keusahawanan berkait dengan niat dan tindakan manakala pemikiran keusahawanan pula melibatkan kepercayaan dan sikap. Pemikiran Keusahawanan (PK) merupakan antara kemahiran kritikal yang perlu dimiliki oleh pelajar abad ke-21 (Bacigalupo et al., 2016; Department for Children Schools and Families, 2010). Justeru, beberapa negara mula menumpukan kepada penerapan elemen pemikiran keusahawanan dalam kurikulum (Saavedra \& Opfer, 2012) bagi menyediakan pelajar-pelajar untuk dunia perniagaan yang lebih mencabar di samping menyediakan individu yang mantap dari segi sosial dan ekonomi (Deveci \& Cepni, 2017). Tambahan lagi, kemahiran pemikiran keusahawanan ini sangat membantu dalam membentuk individu yang kreatif, inovatif, berani mengambil risiko dan menitikberatkan pembangunan sosial (Antonites \& Vuuren, 2005; European Commission, 2011; Kuratko, 2005; Von Kortzfleisch et al., 2013).

Krueger (2005) mentakrifkan Pemikiran keusahawanan (PK) sebagai situasi kognitif yang mencari idea dan peluang yang kreatif dan inovatif. PK juga didefinisikan sebagai kebolehan untuk mengenal pasti peluang dalam pasaran dan meneroka cara yang bersesuaian untuk menggunakannya (Bacigalupo et al., 2016). Dalam hal ini, PK bukanlah pemikiran yang diajar untuk menjadi usahawan semata-mata, tetapi 
PK adalah kemahiran yang dapat memperkasa sumber manusia, kebolehpasaran kerja dan persaingan. Selain itu, PK juga dirujuk sebagai kebolehan menyelesaikan masalah (Krueger, 2007). Individu yang mempunyai PK ini dapat melihat sesuatu keadaan atau fenomena di luar kotak dan sentiasa terbuka kepada peluang pembelajaran baharu.

Rentetan daripada konsep PK ini, timbul satu konsep baharu yang dinamakan Pemikiran Sains Keusahawanan (PSK) yang telah diasaskan oleh Prof. Dr. Lilia Halim dan Prof. Dr. Nor Aishah Buang (Muhammad Syukri et al., 2013). Konsep PSK ialah suatu konsep pengajaran dan pembelajaran sains untuk melahirkan pelajar yang memiliki pemikiran keusahawanan. Dalam kajian ini, PSK dirujuk sebagai kemahiran berfikir reka bentuk berdasarkan pengetahuan sains dan orientasi keusahawanan (Nor Aishah, Lilia, \& T. Subahan, 2009). Rajah 1 menunjukkan konstruk-kontruk dalam PSK berdasarkan Model Pemikiran Sains Keusahawanan Nor Aishah Buang et al.(2009).

Rajah 1: Model Pembelajaran Pemikiran Sains Keusahawanan

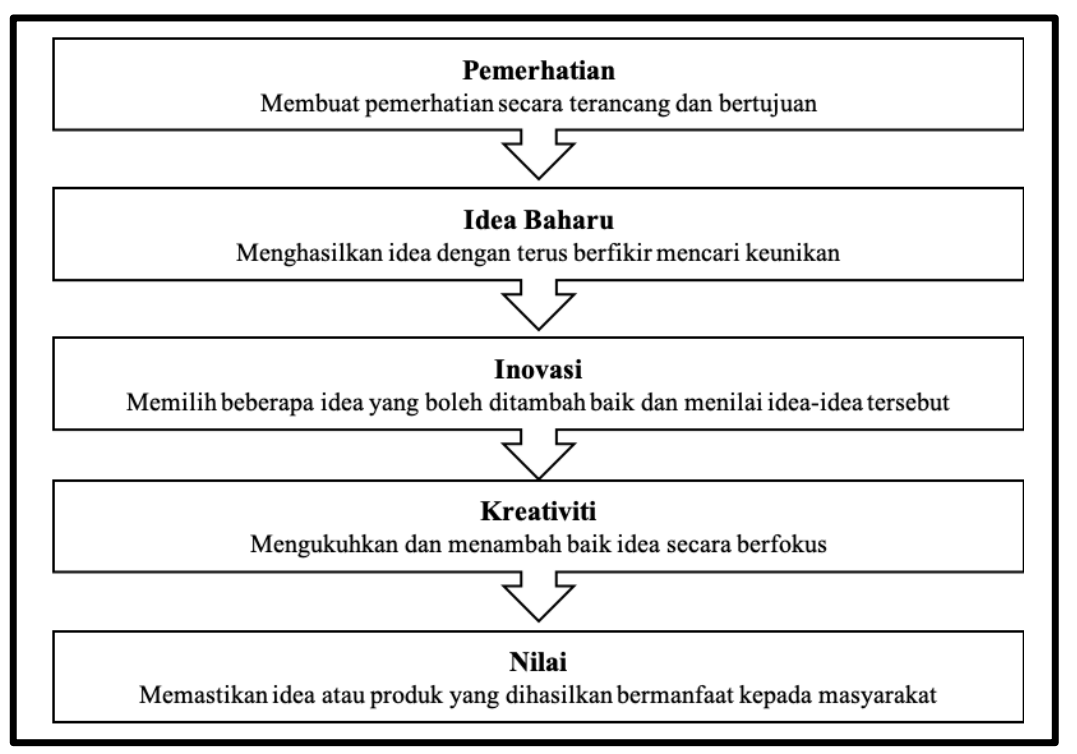

Tuntasnya, pemikiran sains keusahawanan yang merangkumi literasi sains dan kemahiran reka bentuk kejuruteraan sangat diperlukan dalam melahirkan generasi pencipta (Afriana et al., 2016; Committee on STEM Education, 2018; Jin \& Bierma, 2013; Kennedy \& Odell, 2014; Kuenzi, 2011; McDonald, 2016; Zollman, 2012). Berdasarkan Laporan PISA 2018 (Schleicher, 2019), skor purata pelajar Malaysia dari aspek literasi sains hanya 438, di bawah skor purata antarabangsa iaitu 489. Senario ini amat membimbangkan lantaran negara meletakkan hasrat yang tinggi menjelang 2030 untuk melahirkan bangsa pencipta. Ramai tidak menyedari bahawa kemahiran penciptaan perlu bermula di peringkat rendah lagi bagi membantu meningkatkan kemahiran berfikir secara kritis dan minat terhadap mata pelajaran Sains (Bybee, 2013; Hoachlander \& Yanofsky, 2011; Katz, 2010; National Research Council, 2011). Hal ini jelas menunjukkan betapa pentingnya pemupukan pemikiran sains keusahawanan dalam kalangan pelajar.

\section{Model Pengukuran Rasch}

Bagi mengukur kesahan dan kebolehpercayaan dalam item instrumen UPSK, Model Pengukuran Rasch (MPR) telah digunakan. Model Pengukuran Rasch merupakan penyelesaian efektif dalam penyediaan kesahan dan kebolehpercayaan instrumen yang tinggi melalui penghasilan statistik yang mendalam (Trevor G. Bond \& Fox, 2015). MPR menganalisis keupayaan setiap responden yang menjawab instrumen dan mengukur kesukaran bagi setiap item dalam instrumen (Wolins et al., 1982). Selain itu, MPR mampu mengukur sifat terpendam (latent trait) seperti pemikiran dan perasaan manusia (Azrilah et al., 2015).

MPR yang dibangunkan berdasarkan Teori Respons Item ini adalah antara model statistik yang mencukupi kerana dapat mengukur kesukaran item dan keupayaan orang yang diuji pada masa yang 
sama (Deane et al., 2016). Rentetan daripada itu, MPR dapat mengenal pasti kesahan dan kebolehpercayaan item dan responden. Tambahan lagi, analisis Rasch dapat digunakan untuk menjalankan kesahan konstruk dari aspek polariti item, kesesuaian item dan responden serta keekadimensian.

Sungguhpun analisis Rasch mungkin memerlukan proses yang lebih lama daripada analisis tradisional, analisis Rasch mampu memberikan pemahaman yang lebih mendalam tentang kekuatan dan kelemahan instrumen (Boone \& Scantlebury, 2005). Bond dan Fox (2007) menegaskan bahawa MPR adalah penyelesaian yang berkesan dalam membangunkan instrumen yang sangat sah dan boleh dipercayai melalui analisis statistik. Bersandarkan kekuatan-kekuatan yang dinyatakan ini, pengkaji menggunakan analisis Rasch untuk menganalisis kesahan dan kebolehpercayaan instrumen UPSK.

\section{Metod Kajian}

\section{Reka bentuk dan Subjek Kajian}

Kajian ini dijalankan secara tinjauan ke atas 166 orang pelajar Tahun Lima yang dipilih secara rawak dari lima buah sekolah rendah di daerah Tawau, Sabah. Para pelajar adalah dalam lingkungan umur 10 hingga 11 tahun.

\section{Instrumentasi}

Pemikiran sains keusahawanan merupakan keupayaan dalam mencipta dan membuat penambahbaikan terhadap sesuatu produk, idea atau proses sehingga produk tersebut mempunyai nilai tambah dari aspek sosial mahupun ekonomi. Dalam hal ini, hubungkait konsep sains yang diperoleh melalui bilik darjah dan kemampuan guru dalam memupuk PSK akan mencetuskan inovasi untuk disesuaikan dengan situasi yang berlaku dan diperlukan dalam kehidupan seharian pelajar (Venuvinod \& Sun, 2002). Sandaran inilah yang digunakan dalam pembinaan item soalan dalam ujian pemikiran sains keusahawanan (UPSK).

Dalam menentukan bentuk soalan ujian yang digunakan dalam mengukur pemikiran sains keusahawanan setiap individu, bentuk soalan ujian terbuka digunakan. Penggunaan soalan terbuka dapat membantu dalam mendapatkan variasi dalam idea responden (Chen et al., 2020), memberikan gambaran tentang tahap pengetahuan responden (Clarke \& Holt, 2019) dan membantu pengkaji mengenal pasti miskonsepsi dalam kalangan responden (Schuetz, 2008). Pengkaji memilih soalan ujian terbuka agar dapat disesuaikan dengan lima konstruk dalam PSK (Nor Aishah, Lilia, \& T. Subahan, 2009) iaitu pemerhatian, idea baharu, inovasi, kreativiti dan nilai.

Ujian Pemikiran Sains Keusahawanan merangkumi sepuluh item soalan terbuka yang memerlukan pelajar untuk menjawab soalan dalam pernyataan dan lakaran idea. Item soalan dibangunkan dengan merujuk kepada kandungan DSKP Sains Tahun Lima di bawah tema Sains Fizikal serta Teknologi dan Kehidupan Lestari (Bahagian Pembangunan Kurikulum, 2014:61-79). Soalan utama yang diutarakan meminta pelajar untuk menghasilkan suatu rekaan telefon bimbit untuk kegunaan masyarakat pada masa hadapan. Konteks penggunaan telefon bimbit dipilih kerana ia terkandung dalam DSKP di bawah tema Sains Fizikal. Pelajar kemudiannya diberikan gambar rangsangan dan diberi sepuluh item soalan. Item disusun mengikut kelompok konstruk bagi membolehkan pelajar mengorganisasi jawapan dan seterusnya mengarah kepada dapatan yang diharapkan dalam kajian.

Dalam konstruk pemerhatian, pelajar perlu membuat pemerhatian secara terancang dan bertujuan. Item pertama mengkehendakkan pelajar untuk menyatakan bahan yang digunakan untuk membuat telefon bimbit manakala item kedua memerlukan pelajar untuk menyatakan reka bentuk telefon bimbit yang diperhatikan. Seterusnya, dalam konstruk idea baharu, pelajar perlu menghasilkan idea dengan terus berfikir mencari keunikan. Pelajar perlu mencari keunikan atau kelebihan dengan menyatakan kelebihan menggunakan bahan dan reka bentuk yang dinyatakan dalam langkah pemerhatian. 
Dalam konstruk inovasi, item kelima mengkehendaki pelajar untuk memilih tiga idea yang boleh ditambah baik dan diubah suai untuk menghasilkan telefon bimbit masa hadapan manakala item keenam meminta pelajar untuk menyatakan sebab-sebab pemilihan idea yang dinyatakan. Seterusnya, merupakan konstruk kreativiti yang memerlukan pelajar untuk mengukuhkan dan menambah baik idea secara berfokus. Item ketujuh memfokuskan pelajar untuk mengukuhkan dan menambah baik idea-idea yang telah dipilih bagi ciptaan telefon bimbit baharu. Dalam item ini, mereka diminta untuk melakar dan melabel ciri-ciri baharu pada model ciptaan mereka. Seterusnya, item kelapan pula meminta pelajar untuk melengkapkan butiran tentang produk ciptaan mereka dengan menyatakan nama produk, harga yang ditawarkan dan kumpulan sasaran pembeli.

Akhir sekali adalah konstruk nilai di mana pelajar perlu memastikan produk ciptaan mereka memberi manfaat untuk masyarakat. Item kesembilan mengkehendaki pelajar untuk menyatakan manfaat dari aspek penjimatan kos manakala item kesepuluh pula dari aspek nilai dan etika dalam penciptaan produk. Jadual 1 menunjukkan item soalan bagi Ujian Pemikiran Sains Keusahawanan (UPSK) mengikut konstruk.

Masa menjawab yang diperuntukkan bagi menjawab kesemua item soalan adalah selama 60 minit. Rubrik penskoran bagi konstruk Ujian Pemikiran Sains Keusahawanan diadaptasi daripada Ho, Wang dan Cheng (2013). Setiap item yang disediakan dalam ujian ini membawa skor minimum 0 dan skor maksimum tiga. Setiap skor ditentukan berdasarkan aras jawapan pelajar iaitu dari 0 hingga 3 markah bagi setiap item. Jadual 2 menunjukkan contoh penetapan skor mengikut respon pelajar bagi salah satu konstruk dalam UPSK iaitu inovasi.

Jadual 1: Item soalan bagi Ujian Pemikiran Sains Keusahawanan mengikut konstruk

\begin{tabular}{|c|c|c|c|}
\hline Konstruk & Definisi konstruk & Item & Soalan \\
\hline \multirow[t]{2}{*}{ Pemerhatian } & \multirow{2}{*}{$\begin{array}{l}\text { Membuat pemerhatian } \\
\text { secara terancang dan } \\
\text { bertujuan. }\end{array}$} & $1 \mathrm{a}$ & $\begin{array}{l}\text { Nyatakan bahan yang digunakan } \\
\text { untuk membuat telefon bimbit. }\end{array}$ \\
\hline & & $1 b$ & $\begin{array}{l}\text { Nyatakan reka bentuk telefon bimbit } \\
\text { yang dapat anda perhatikan. }\end{array}$ \\
\hline \multirow[t]{2}{*}{ Idea Baharu } & \multirow[t]{2}{*}{$\begin{array}{lr}\text { Menghasilkan idea } \\
\text { dengan mencari keunikan }\end{array}$} & $2 a$ & $\begin{array}{l}\text { Apakah kelebihan menggunakan } \\
\text { bahan yang anda nyatakan untuk } \\
\text { membina telefon bimbit tersebut? }\end{array}$ \\
\hline & & $2 b$ & $\begin{array}{l}\text { Apakah kelebihan menggunakan } \\
\text { reka bentuk telefon bimbit yang anda } \\
\text { nyatakan? }\end{array}$ \\
\hline \multirow[t]{2}{*}{ Inovasi } & \multirow[t]{2}{*}{$\begin{array}{l}\text { Memilih beberapa idea } \\
\text { yang boleh ditambah baik } \\
\text { dan menilai idea-idea } \\
\text { tersebut }\end{array}$} & $3 a$ & $\begin{array}{l}\text { Berdasarkan idea-idea yang anda } \\
\text { telah nyatakan dalam soalan } 2 \text {, pilih } \\
\text { tiga (3) idea yang anda boleh tambah } \\
\text { baik untuk menghasilkan telefon } \\
\text { bimbit masa hadapan. }\end{array}$ \\
\hline & & $3 b$ & $\begin{array}{l}\text { Mengapakah anda memilih idea-idea } \\
\text { di atas? Berikan tiga (3) sebab. }\end{array}$ \\
\hline \multirow[t]{2}{*}{ Kreativiti } & \multirow[t]{2}{*}{$\begin{array}{lr}\text { Mengukuhkan } & \text { dan } \\
\text { menambah baik idea } \\
\text { secara berfokus }\end{array}$} & $4 a$ & $\begin{array}{l}\text { Kukuhkan dan tambah baik tiga (3) } \\
\text { idea yang anda telah pilih bagi } \\
\text { ciptaan telefon bimbit baharu untuk } \\
\text { kegunaan masyarakat pada masa } \\
\text { hadapan. Lakarkan dan labelkan ciri } \\
\text { baharu pada model anda dalam } \\
\text { ruangan yang disediakan. }\end{array}$ \\
\hline & & $4 b$ & $\begin{array}{l}\text { Lengkapkan butiran tentang produk } \\
\text { anda dengan menyatakan nama } \\
\text { produk, harga yang ditawarkan dan } \\
\text { kumpulan sasaran pembeli. }\end{array}$ \\
\hline Nilai & $\begin{array}{l}\text { Memastikan idea atau } \\
\text { produk yang dihasilkan }\end{array}$ & $5 \mathrm{a}$ & $\begin{array}{l}\text { Nyatakan manfaat produk anda } \\
\text { kepada masyarakat dari aspek }\end{array}$ \\
\hline
\end{tabular}



DOI: https://doi.org/10.47405/mjssh.v5i10.504

\begin{tabular}{|c|c|c|}
\hline \multirow{2}{*}{$\begin{array}{l}\text { bermanfaat } \\
\text { masyarakat }\end{array}$} & \multirow[t]{2}{*}{ kepada } & penjimatan kos dan fungsi produk. \\
\hline & & $\begin{array}{l}\text { Nyatakan manfaat produk anda } \\
\text { kepada masyarakat dari aspek nilai } \\
\text { dan etika dalam penciptaan produk. }\end{array}$ \\
\hline
\end{tabular}

Jadual 2: Item soalan bagi Ujian Pemikiran Sains Keusahawanan mengikut konstruk

\begin{tabular}{|c|c|c|c|}
\hline Konstruk & Kebolehan & Panduan Skor & Aras dan Skor \\
\hline \multirow{8}{*}{$\begin{array}{l}\text { 3. Inovasi } \\
\text { (Memilih idea- } \\
\text { idea yang } \\
\text { boleh } \\
\text { ditambah baik } \\
\text { dan membuat } \\
\text { penilaian ke } \\
\text { atas idea-idea } \\
\text { tersebut) }\end{array}$} & \multirow[t]{4}{*}{$\begin{array}{l}3.2 \text { Membuat penilaian ke } \\
\text { atas idea-idea yang telah } \\
\text { dipilih. }\end{array}$} & $\begin{array}{lr}\text { 3.2.4 Pelajar } & \text { dapat } \\
\text { memberikan } 3 & \text { faktor } \\
\text { pemilihan idea. } & \end{array}$ & $\begin{array}{l}\text { Aras } 4 \\
3 \text { markah }\end{array}$ \\
\hline & & $\begin{array}{lr}\text { 3.2.3 Pelajar } & \text { dapat } \\
\text { memberikan } 2 & \text { faktor } \\
\text { pemilihan idea. } & \end{array}$ & $\begin{array}{l}\text { Aras } 3 \\
2 \text { markah }\end{array}$ \\
\hline & & $\begin{array}{lr}3.2 .2 \quad \text { Pelajar } & \text { dapat } \\
\text { memberikan } 1 & \text { faktor } \\
\text { pemilihan idea } & \\
\end{array}$ & $\begin{array}{l}\text { Aras } 2 \\
1 \text { markah }\end{array}$ \\
\hline & & $\begin{array}{l}\text { 3.2.1 Pelajar tidak dapat } \\
\text { memberikan } 1 \text { faktor } \\
\text { pemilihan idea. }\end{array}$ & $\begin{array}{l}\text { Aras } 1 \\
0 \text { markah }\end{array}$ \\
\hline & \multirow{4}{*}{$\begin{array}{l}3.1 \\
\text { Memilih idea-idea yang } \\
\text { boleh ditambah baik } \\
\text { untuk menghasilkan } \\
\text { ciptaan baharu. }\end{array}$} & $\begin{array}{lll}\text { 3.1.4 } & \text { Pelajar } & \text { dapat } \\
\text { memilih } 3 \text { idea } & \end{array}$ & $\begin{array}{l}\text { Aras } 4 \\
3 \text { markah }\end{array}$ \\
\hline & & $\begin{array}{l}3.1 .3 \quad \text { Pelajar dapat } \\
\text { memilih } 2 \text { idea }\end{array}$ & $\begin{array}{l}\text { Aras } 3 \\
2 \text { markah }\end{array}$ \\
\hline & & $\begin{array}{lll}3.1 .2 & \text { Pelajar } & \text { dapat } \\
\text { memilih } 1 \text { idea } & \end{array}$ & $\begin{array}{l}\text { Aras } 2 \\
1 \text { markah }\end{array}$ \\
\hline & & $\begin{array}{l}\text { 3.1.1 Pelajar tidak dapat } \\
\text { memilih } 1 \text { idea }\end{array}$ & $\begin{array}{l}\text { Aras } 1 \\
0 \text { markah }\end{array}$ \\
\hline
\end{tabular}

Sumber: Ho et al.(2013)

\section{Prosedur untuk Menganalisis Data}

Dapatan kajian dianalisis bagi menentukan kebolehpercayaan dan kesahan dari aspek kesahan kandungan dan kesahan konstruk. Bagi menentukan nilai persetujuan kesahan kandungan, pengkaji menggunakan Indeks Kesahan Kandungan (Content Validation Index, CVI). CVI memberikan purata penilaian skor bagi semua item yang dinilai oleh pakar. Davis (1992) menyatakan bahawa nilai CVI yang diterima bagi instrument yang baharu dibangunkan ialah $\geq 0.80$. Polit et al (2007) mencadangkan nilai 0.78 dan ke atas bagi kes kesahan yang melibatkan tiga orang pakar atau lebih. Kajian ini menggunakan ketetapan yang dicadangkan oleh Davis (1992) iaitu dengan nilai 0.80 bagi instrumen baharu. Analisis CVI berdasarkan Polit \& Beck (2006) adalah seperti di bawah.

$$
\text { Indeks Kesahan Kandungan }(\mathrm{CVI})=\frac{\text { Jumlah skor yang dipersetujui pakar }}{\text { Jumlah skor penuh }}
$$

Bagi aspek kesahan konstruk dan kebolehpercayaan item, perisian WINSTEPS versi 3.73 digunakan. $\mathrm{Hal}$ ini bagi memastikan jaminan kualiti instrumen dan ketepatan data yang diperoleh oleh pengkaji sebelum digunakan dalam konteks kajian sebenar.

Pertamanya, analisis nilai PTMEA-CORR dilakukan untuk mengenal pasti polariti. Nilai PTMEACORR yang positif menunjukkan bahawa item dapat mengukur dengan baik apa yang ingin diukur dan sebaliknya jika nilainya adalah negatif. Kesesuaian item pula dianalisis dengan merujuk kepada nilai Outfit MNSQ, Outfit ZSTD dan PTMEA-CORR (Trevor G. Bond \& Fox, 2015; Boone et al., 2014; 
Waugh, 2012). Nilai kesesuaian item ini menunjukkan sama ada item tersebut dapat menjalankan pengukuran yang sepatutnya (Sumintono dan Widhiarso, 2015). Item yang tidak berada dalam lingkungan julat Indeks Kesesuaian Item (Jadual 3) perlu diubah suai atau digugurkan agar nilai kesesuaian item tdapat ditingkatkan (Sumintono \& Widhiarso, 2015).

Jadual 3: Indeks Kesesuaian Item

\begin{tabular}{ll}
\hline Statistik & Indeks \\
\hline Outfit MNSQ & $0.50-1.50$ \\
Outfit ZSTD. & $-2.00-2.00$ \\
PTMEA-CORR & $0.40-0.85$ \\
\hline
\end{tabular}

Sumber: Boone et al.(2014)

Selain itu, model Rasch juga dapat menunjukkan kesesuaian responden berdasarkan nilai dengan merujuk kepada nilai 'MEASURE', Outfit MNSQ, dan Outfit ZSTD (Edwards \& Alcock, 2010).

Nevin et al.(2015) menegaskan bahawa sekiranya nilai Outfit ZSTD melebihi 2.0 dan nilai MEASURE adalah tinggi, wujud kebarangkalian bahawa pelajar yang cemerlang tidak menjawab dengan berhatihati item yang rendah arasnya. Jika nilai Outfit ZSTD melebihi 2.0 tetapi nilai MEASURE pula rendah, berkemungkinan bahawa pelajar yang berkeupayaan rendah dapat menjawab item yang 'susah' dengan betul. Oleh itu, responden yang tidak sesuai akan disingkirkan bagi meningkatkan kesahan instrumen (Lamoureux et al., 2008).

Pengkaji turut menilai keekadimensian instrumen untuk memastikan instrumen benar-benar dapat mengukur pemikiran sains keusahawanan (Shea et al., 2009; Sumintono \& Widhiarso, 2015). Analisis Komponen Utama (Principal Component Analysis, PCA) menyediakan kriteria keekadimensian berdasarkan 'raw variance explained by measures' (Sumintono dan Widhiarso, 2015). Nilai 'raw variance explained by measures' yang diterima perlu melebihi $20 \%$, baik jika melebihi $40 \%$ dan cemerlang jika melebihi $60 \%$. Sementara itu, nilai bagi 'unexplained variance in first contrast' tidak boleh melebihi $15 \%$.

Jadual 4: Keekadimensian berdasarkan Raw Variance Explained by Measures

\begin{tabular}{ll}
\hline Nilai & Tafsiran \\
\hline$\geq 20 \%$ & Diterima \\
$\geq 40 \%$ & Baik \\
$\geq 60 \%$ & Cemerlang \\
\hline
\end{tabular}

Sumber: Sumintono \& Widhiarso (2015)

Dari aspek kebolehpercayaan pula, pengkaji merujuk kepada Sumintono dan Widhiarso (2015) bagi nilai Alpha Cronbach (KR-20), indeks kebolehpercayaan item dan responden serta pengasingan item dan responden (Jadual 5).

Jadual 5: Kebolehpercayaan dalam Analisis Rasch

\begin{tabular}{lll}
\hline Statistik & Indeks & Tafsiran \\
\hline Alpha Cronbach (KR-20) & $<0.5$ & Rendah \\
& $<0.6$ & Sederhana \\
& $0.6-0.7$ & Baik \\
& $0.7-0.8$ & Tinggi \\
& $0.9-1.0$ & Sangat Tinggi \\
\hline Kebolehpercayaan Item & $<0.67$ & Rendah \\
dan Responden & $0.67-0.80$ & Mencukupi \\
& $0.81-0.90$ & Baik \\
& $0.91-0.94$ & Sangat Baik \\
& $>0.94$ & Cemerlang \\
\hline
\end{tabular}


DOI: https://doi.org/10.47405/mjssh.v5i10.504

\begin{tabular}{ll}
$\begin{array}{l}\text { Pengasingan Item } \\
\text { dan Responden }\end{array}$ & $\begin{array}{l}\text { Nilai pengasingan yang tinggi menunjukkan agihan yang } \\
\text { baik antara item dan responden serta menjelaskan pecahan } \\
\text { kumpulan item dan responden dalam instrumen }\end{array}$ \\
\hline
\end{tabular}

Sumber: Sumintono \& Widhiarso (2015)

\section{Hasil Kajian}

\section{Kesahan Kandungan Instrumen UPSK}

Kesahan kandungan menunjukkan sejauh mana item cukup mewakili kandungan sifat yang ingin diukur oleh pengkaji (Creswell \& Creswell, 2017). Kline (2005) menyatakan bahawa semakan pakar adalah perlu bagi memastikan ketepatan konstruk serta kejelasan isi kandungannya. Justeru, bagi meningkatkan kesahan kandungan item-item instrumen UPSK, proses kesahan kandungan dijalankan dengan bantuan lima orang panel pakar dalam bidang pemikiran sains keusahawanan, Pendidikan Sains dan STEM. Pengkaji menggunakan borang penilaian item yang diadaptasi daripada Lembaga Peperiksaan Malaysia (LPM, 2013). Panel menilai item UPSK dari aspek keakuran, ketepatan dan kejelasan serta kesesuaian. Komen daripada pakar dicatatkan dan diambil perhatian untuk proses penambahbaikan item instrumen UPSK. Jadual 6 menunjukkan senarai panel kesahan kandungan yang terlibat.

Jadual 6: Panel Kesahan Kandungan Ujian Pemikiran Sains Keusahawanan (UPSK)

\begin{tabular}{|c|c|c|c|}
\hline Nama & Wakil & Jawatan & Kepakaran \\
\hline Pakar A & Universiti & Profesor (PhD) & Pemikiran Sains Keusahawanan \\
\hline Pakar B & IPGM & $\begin{array}{l}\text { Pensyarah Akademik } \\
\text { Jabatan STEM (PhD) }\end{array}$ & Kurikulum dan Pengajaran (Sains) \\
\hline Pakar C & IPGM & $\begin{array}{l}\text { Pensyarah Akademik } \\
\text { Jabatan STEM }\end{array}$ & Pendidikan Sains \\
\hline Pakar D & Sekolah & $\begin{array}{l}\text { Ketua Panitia Sains } \\
(\mathrm{PhD})\end{array}$ & STEM dan Kreativiti Saintifik \\
\hline Pakar E & Sekolah & Jurulatih Utama Sains & Pendidikan Sains Sekolah Rendah \\
\hline
\end{tabular}

Berdasarkan Jadual 7, nilai Indeks kesahan kandungan yang diperoleh selepas melalui kesahan pakar adalah 0.93. Nilai CVI ini menepati syarat $\geq 0.80$ seperti yang ditetapkan oleh Davis (1992) abgi instrumen baharu. Indeks CVI 0.93 menunjukkan bahawa kesahan kandungan instrumen UPSK menurut panel pakar adalah sangat tinggi dan boleh diterima.

Jadual 7: Keputusan Indeks Kesahan Kandungan (CVI) instrumen

Ujian Pemikiran Sains Keusahawanan

\begin{tabular}{llrl}
\hline Pakar & Indeks Kesahan kandungan (CVI) & Pandangan Pakar \\
\hline Pakar A & 0.81 & Diterima & \\
Pakar B & 0.81 & Diterima & \\
Pakar C & 0.94 & Diterima & \\
Pakar D & 0.98 & Diterima & \\
Pakar E & 0.97 & Diterima & \\
\hline Indeks Kesahan Kandungan Keseluruhan & $\mathbf{0 . 9 0 2}$ &
\end{tabular}

Indeks Kesahan Kandungan Keseluruhan $\quad \mathbf{0 . 9 0 2}$

\section{Kesahan Konstruk Instrumen UPSK}

\section{Polariti Item}


DOI: https://doi.org/10.47405/mjssh.v5i10.504

Analisis polariti item menggunakan nilai PTMEA-CORR menunjukkan item-item dalam UPSK bergerak dalam satu arah yang sama mengikut konstruk yang diukur (J. Linacre, 2002). Nilai positif menunjukkan semua item yang digunakan berfungsi ke arah yang selari manakala nilai negatif menunjukkan bahawa item perlu diperbaiki atau digugurkan. Berdasarkan Rajah 2, nilai minimum PTMEA-CORR adalah 0.54 manakala nilai maksimum ialah 0.90 .

Rajah 2: Analisis nilai polariti item

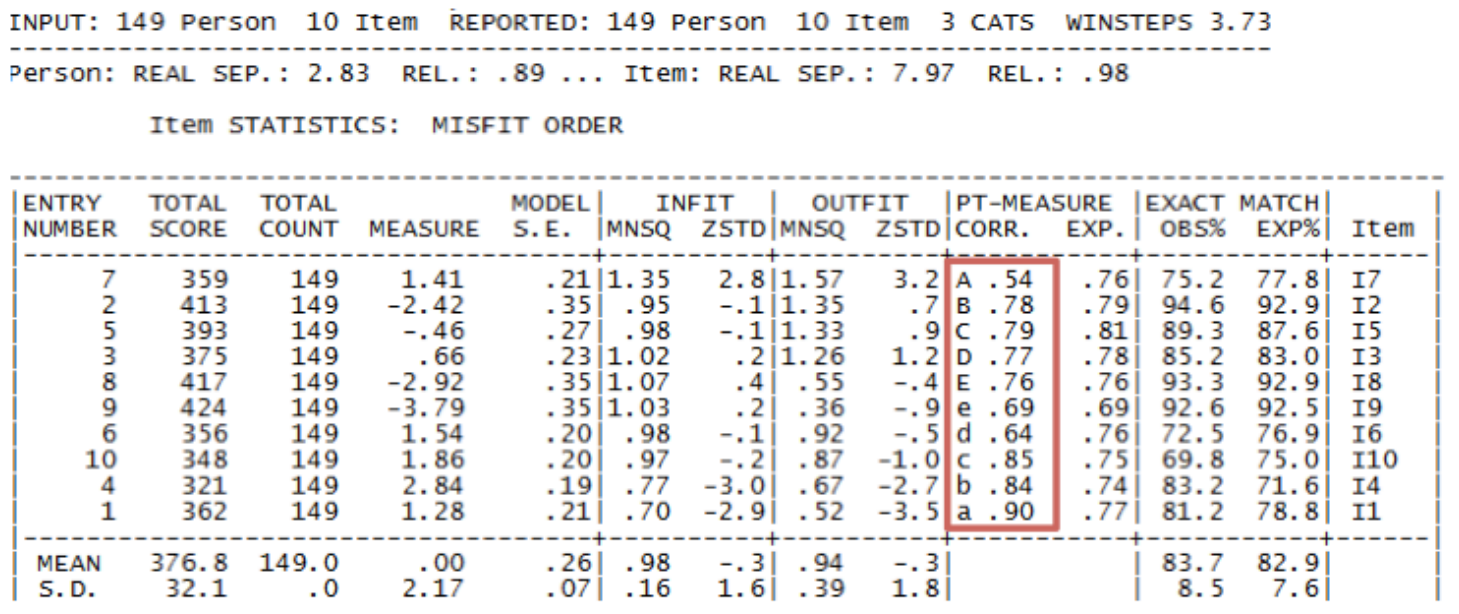

\section{Kesesuaian Item}

Item yang sesuai berada pada nilai 0.50 hingga 1.50 berdasarkan outfit Mean Square (MNSQ). Boone et al. (2014) menetapkan bahawa julat kesesuaian item yang produktif adalah antara 0.5 hingga 1.5. Berdasarkan Jadual 10, terdapat tiga item yang berada di luar lingkungan julat iaitu item 4, 7 dan 9 . Boone et al. (2014) dan Abdul Aziz et al.(2014) menyatakan bahawa item-item yang berada di luar lingkungan julat dan tidak memenuhi ketiga-tiga kriteria dianggap tidak sesuai. Akan tetapi, sekiranya item memenuhi salah satu kriteria, item tersebut perlu dikekalkan (Sumintono \& Widhiarso, 2015). Jadual 8 menunjukkan bahawa kesemua item memenuhi sekurang-kurangnya satu kriteria. Oleh itu, tiada sebarang penyingkiran item dilakukan dalam instrumen UPSK ini.

Jadual 8: Urutan Ketidaksesuaian Item

\begin{tabular}{lllll}
\hline Item & $\begin{array}{l}\text { Outfit MNSQ } \\
(\mathbf{0 . 5 0 - 1 . 5 0 )}\end{array}$ & $\begin{array}{l}\text { Outfit ZSTD } \\
\mathbf{( - 2 . 0 - 2 . 0 )}\end{array}$ & $\begin{array}{l}\text { PTMEA-CORR } \\
\mathbf{( 0 . 4 0 - 0 . 8 5 )}\end{array}$ & Keputusan \\
\hline I7 & $\mathbf{1 . 5 7}$ & $\mathbf{3 . 2}$ & 0.54 & dikekalkan \\
I2 & 1.35 & 0.7 & 0.78 & dikekalkan \\
I5 & 1.33 & 0.9 & 0.79 & dikekalkan \\
I3 & 1.26 & 1.2 & 0.77 & dikekalkan \\
I8 & 0.55 & -0.4 & 0.76 & dikekalkan \\
I9 & $\mathbf{0 . 3 6}$ & -0.9 & 0.69 & dikekalkan \\
I6 & 0.92 & -0.5 & 0.64 & dikekalkan \\
I10 & 0.87 & -1.0 & 0.85 & dikekalkan \\
I4 & 0.67 & $\mathbf{- 2 . 7}$ & 0.84 & dikekalkan \\
I1 & 0.52 & $\mathbf{- 3 . 5}$ & $\mathbf{0 . 9 0}$ & dikekalkan \\
\hline
\end{tabular}

\section{Kesesuaian Responden}

Jadual 9 menunjukkan responden yang memberi respon yang paling tidak sesuai dengan analisis Rasch. Responden disusun mengikut nilai Outifit ZSTD yang tertinggi. Kesemua responden berada dalam nilai julat Outifit ZSTD yang diterima manakala tujuh responden $(063,100,127,166,004,002$ dan 022) 
DOI: https://doi.org/10.47405/mjssh.v5i10.504

pula mencatatkan nilai yang melebihi 2.0. Responden yang memberikan bacaan PTMEA-CORR yang negatif pula menunjukkan mereka membuat keputusan luar daripada kebiasaan.

Jadual 9: Urutan Ketidaksesuaian Responden

\begin{tabular}{llll}
\hline Responden & $\begin{array}{l}\text { Outfit MNSQ } \\
(\mathbf{0 . 5 0 - 1 . 5 0 )}\end{array}$ & $\begin{array}{l}\text { Outfit ZSTD } \\
\mathbf{( - 2 . 0 - 2 . 0 )}\end{array}$ & $\begin{array}{l}\text { PTMEA-CORR } \\
(\mathbf{0 . 4 0 - 0 . 8 5 )}\end{array}$ \\
\hline 063 & 9.90 & 3.9 & -0.38 \\
100 & 9.90 & 4.5 & -0.44 \\
127 & 9.90 & 3.1 & -0.25 \\
166 & 7.33 & 2.5 & -0.12 \\
004 & 5.72 & 2.8 & -0.02 \\
002 & 2.97 & 2.2 & 0.08 \\
022 & 2.97 & 2.2 & 0.08 \\
\hline
\end{tabular}

Selain itu, terdapat 10 orang responden yang mempunyai markah ekstrim (markah maksimum) iaitu pelajar 020, 044, 068, 076, 084, 088, 093, 096, 109, dan 161 (Rajah 3). Seramai 17 responden disingkirkan dan hanya 149 responden sahaja daripada 166 responden yang terlibat dengan analisis yang seterusnya. Sungguhpun demikian, secara keseluruhan, item-item dalam UPSK ini adalah sesuai untuk kebanyakan pelajar $(89.76 \%)$.

Rajah 3: Responden yang mempunyai markah ekstrim

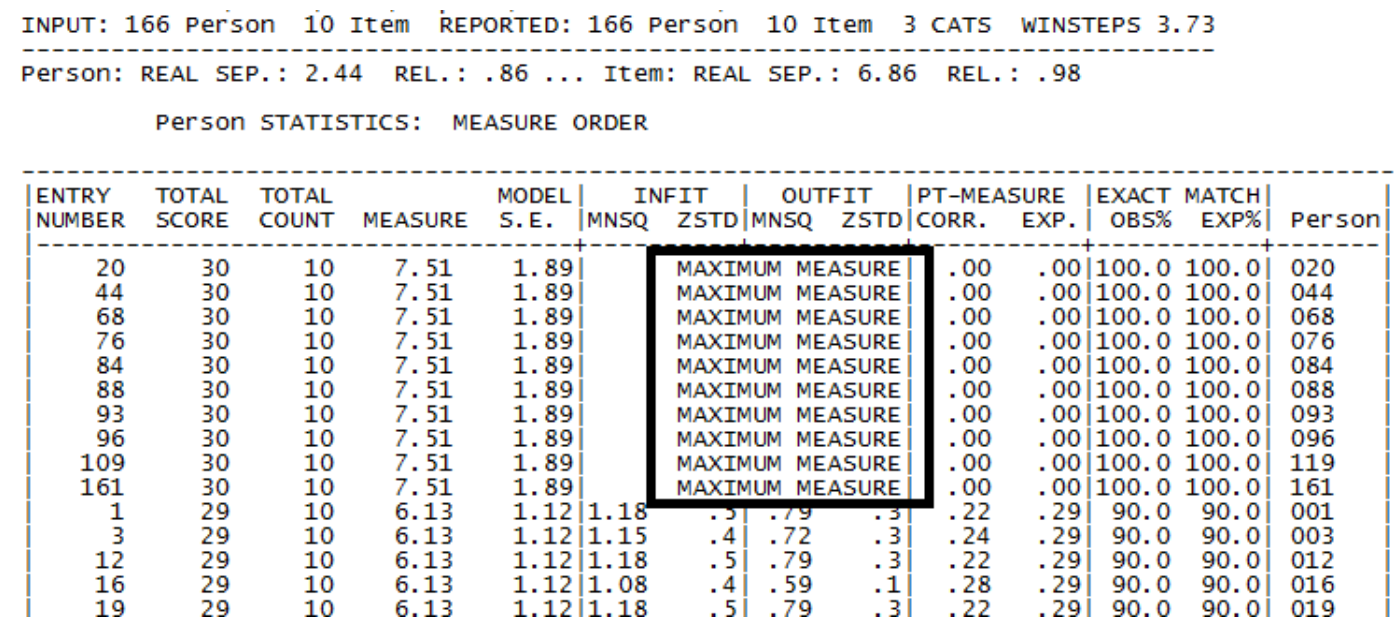

\section{Keekadimensian}

Keekadimensian penting untuk menentukan instrumen yang dibangunkan dapat mengukur dalam satu arah dan menjamin hasil dapatan kajian tidak mengelirukan. Rajah 4 menunjukkan nilai Raw Variance Explained by Measures bagi instrumen PSK ini adalah 66.8\%, tidak jauh daripada jangkaan model Rasch iaitu $65.7 \%$. Nilai yang melebihi indeks $60 \%$ berada pada tahap cemerlang dan terbukti bahawa instrumen UPSK mempunyai keekadimensian yang kuat, yakni benar-benar mengukur konstruk. Nilai 'unexplained variance' bagi kontras pertama adalah kurang daripada 7\%, tidak melebihi had kawalan $15 \%$. 
DOI: https://doi.org/10.47405/mjssh.v5i10.504

Rajah 4: Analisis Komponen Utama

INPUT: 149 Person 10 Item REPORTED: 149 Person 10 Item 3 CATS WINSTEPS 3.73

Table of STANDARDIZED RESIDUAL variance (in Eigenvalue units)

\begin{tabular}{|c|c|c|c|c|c|}
\hline Total raw variance in observation & $=$ & $\begin{array}{l}-\bar{E} \\
30.1\end{array}$ & $100.0 \%$ & & $\begin{array}{r}\text { Modeled } \\
100.0 \%\end{array}$ \\
\hline Raw variance explained by measures & $=$ & 20.1 & $66.8 \%$ & & $65.7 \%$ \\
\hline Raw variance explarned by persons & $=$ & 13.7 & $45.6 \%$ & & $44.9 \%$ \\
\hline Raw variance explained by items & $=$ & 6.4 & $21.2 \%$ & & $20.8 \%$ \\
\hline Raw unexplained variance (tota1) & $=$ & 10.0 & & $100.0 \%$ & $34.3 \%$ \\
\hline Unexplned variance in 1st contrast & $=$ & 2.0 & $6.6 \%$ & $19.7 \%$ & \\
\hline Unexplned variance in 2 nd contrast & $=$ & 1. 5 & $5.0 \%$ & $15.0 \%$ & \\
\hline Unexplned variance in $3 \mathrm{rd}$ contrast & $=$ & 1.2 & $4.0 \%$ & $12.1 \%$ & \\
\hline Unexplned variance in 4 th contrast & $=$ & 1.2 & $3.8 \%$ & $11.6 \%$ & \\
\hline Unexplned variance in 5 th contrast & $=$ & 1.1 & $3.7 \%$ & $11.0 \%$ & \\
\hline
\end{tabular}

\section{Kebolehpercayaan dan Nilai Pengasingan Item dan Responden}

Rajah 5: Analisis Kebolehpercayaan dan Nilai Pengasingan

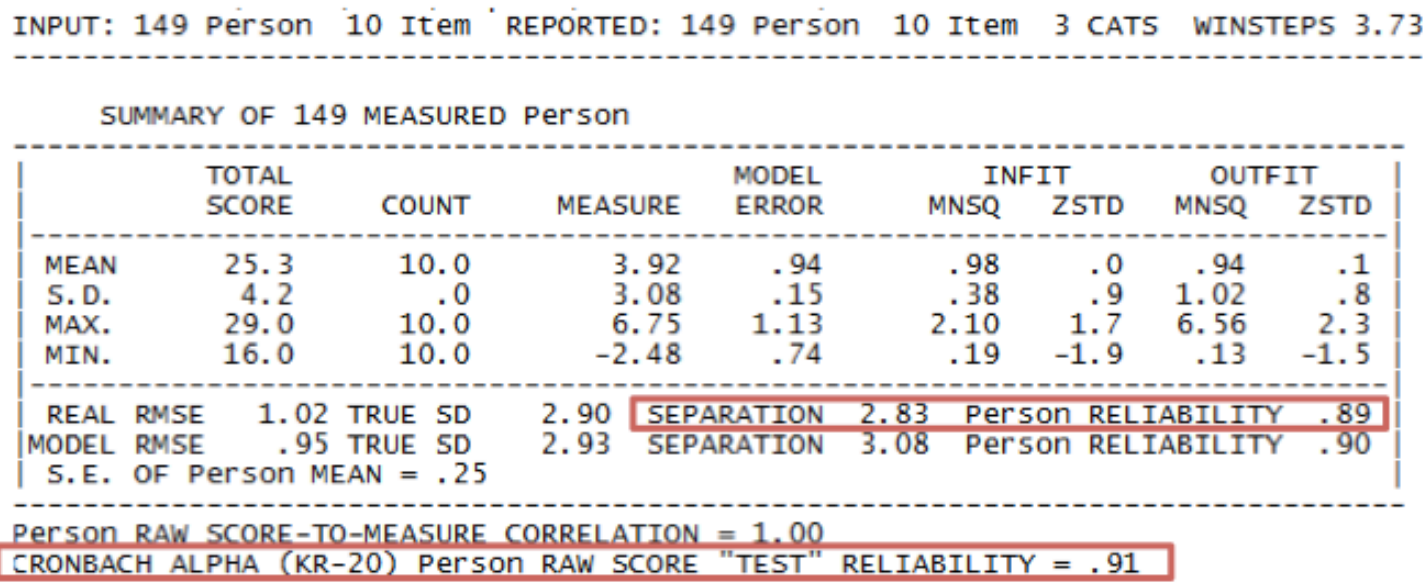

SUMMARY OF 10 MEASURED Item

\begin{tabular}{|c|c|c|c|c|c|c|c|c|}
\hline & \multirow{2}{*}{$\begin{array}{l}\text { TOTAL } \\
\text { SCORE }\end{array}$} & \multirow[b]{2}{*}{ COUNT } & \multirow[b]{2}{*}{ MEASURE } & \multirow{2}{*}{$\begin{array}{l}\text { MODEL } \\
\text { ERROR }\end{array}$} & \multicolumn{2}{|c|}{ INFIT } & \multicolumn{2}{|c|}{ OUTFIT } \\
\hline & & & & & MNSQ & ZSTD & MNSQ & ZSTD \\
\hline $\begin{array}{l}\text { MEAN } \\
\text { S. D. } \\
\text { MAX. } \\
\text { MIN. }\end{array}$ & $\begin{array}{r}376.8 \\
32.1 \\
424.0 \\
321.0\end{array}$ & $\begin{array}{r}149.0 \\
.0 \\
149.0 \\
149.0\end{array}$ & $\begin{array}{r}.00 \\
2.17 \\
2.84 \\
-3.79\end{array}$ & $\begin{array}{l}.26 \\
.07 \\
.35 \\
.19\end{array}$ & $\begin{array}{r}.98 \\
.16 \\
1.35 \\
.70\end{array}$ & $\begin{array}{r}-.3 \\
1.6 \\
2.8 \\
-3.0\end{array}$ & $\begin{array}{r}.94 \\
.39 \\
1.57 \\
.36\end{array}$ & $\begin{array}{r}-.3 \\
1.8 \\
3.2 \\
-3.5\end{array}$ \\
\hline $\begin{array}{c}\text { REAL } \\
\text { MODEL } \\
\text { S.E. }\end{array}$ & $\mathrm{em}$ & $\begin{array}{l}\text { TRUE SD } \\
\text { TRUE SD } \\
=.72\end{array}$ & $\begin{array}{l}2.15 \text { SEP } \\
2.15\end{array}$ & $\begin{array}{l}\text { RATION } \\
\text { RATION }\end{array}$ & $\begin{array}{l}\text { It } \\
\text { It }\end{array}$ & & $\frac{\mathrm{ABILI}}{\mathrm{ABILI}}$ & .98 \\
\hline
\end{tabular}

Jadual 10 menunjukkan nilai bagi Alfa Cronbach (KR-20), kebolehpercayaan dan pengasingan bagi item dan responden bagi instrumen UPSK. Analisis Alfa Cronbach mencatatkan nilai 0.91 menunjukkan kebolehpercayaan instrumen UPSK yang sangat tinggi. Nilai kebolehpercayaan item sebanyak 0.98 dikategorikan sebagai cemerlang (Sumintono \& Widhiarso, 2015). Nilai pengasingan item sebanyak 7.97 pula memberi tafsiran bahawa item dalam instrumen ini adalah baik dan boleh dikategorikan kepada 8 strata item. Nilai pengasingan yang dicatatkan melebihi 2.00 dikategorikan sebagai baik (Linacre, 2003). 
Jadual 10: Nilai bagi Cronbach Alpha (KR-20) dan Kebolehpercayaan dan Pengasingan ItemResponden

\begin{tabular}{lll}
\hline & Nilai & Tafsiran \\
\hline Nilai Alfa Cronbach (KR-20) & 0.91 & Sangat Tinggi \\
Kebolehpercayaan Item & 0.98 & Cemerlang \\
Pengasingan Item & 7.97 & Baik \\
Kebolehpercayaan Responden & 0.89 & Baik \\
Pengasingan Responden & 2.83 & Baik \\
\hline
\end{tabular}

Di samping itu, analisis Rasch juga mencatatkan nilai kebolehpercayaan responden yang baik iaitu sebanyak 0.89 (Sumintono \& Widhiarso, 2015). Bond dan Fox (2007) turut menyokong dengan menyatakan bahawa nilai kebolehpercayaan responden yang lebih tinggi daripada 0.80 menunjukkan bahawa responden memberikan maklum balas yang baik dan konsisten. Nilai pengasingan sebanyak 2.83 adalah 'baik' jika nilainya melebihi 2.00 (Linacre, 2003). Nilai 2.83 juga menunjukkan bahawa responden dapat dikelompokkan kepada 3 strata yang berbeza keupayaan dalam menjawab item dalam instrumen UPSK. Hasil analisis terperinci menggunakan MPR ini membuktikan bahawa instrumen UPSK sangat sesuai digunakan untuk kajian lapangan yang sebenar.

\section{Perbincangan Kajian}

Secara keseluruhannya, analisis kesahan instrumen yang telah dijalankan bagi aspek polariti item, kesesuaian item dan responden serta keekadimensian. Analisis PTMEA-CORR yang positif menunjukkan bahawa semua item bergerak dalam satu arah yang sama dalam mentafsir konstruk yang ingin diukur (Bond \& Fox, 2015). Melalui analisis kesesuaian item, kesemua item dalam instrumen UPSK boleh dikekalkan kerana berada dalam lingkungan julat salah satu kriteria Outfit MNSQ, Outfit ZSTD dan PTMEA-CORR. Bagi kesesuaian responden, daripada 166 orang, seramai 17 orang responden disingkirkan kerana menunjukkan ketidaksesuaian dan skor yang ekstrim. Baki seramai 149 responden dilibatkan dalam analisis kerana menunjukkan respons yang bermakna. Analisis bagi nilai Raw Variance Explained by Measures instrumen UPSK yang ditunjukkan adalah 66.8\% (melebihi $60 \%$ ), membuktikan bahawa instrumen UPSK mempunyai keekadimensian yang tinggi, di mana instrumen ini benar-benar mengukur konstruk pemikiran sains keusahawanan.

Dari aspek kebolehpercayaan, instrumen UPSK mempunyai nilai Alfa Cronbach yang sangat tinggi (0.91), nilai kebolehpercayaan item yang cemerlang (0.98) dan kebolehpercayaan responden yang baik (0.89). Dapatan ini menunjukkan bahawa kebolehpercayaaan instrumen UPSK dalam menilai pemikiran sains keusahawanan pelajar tahun lima di sekolah-sekolah rendah di Sabah adalah tinggi. Klooster et al.(2008) menyatakan bahawa nilai pengasingan item yang baik (7.9) menunjukkan bahawa instrumen UPSK mempunyai lapan strata item yang berbeza tahap manakala nilai pengasingan responden (2.83) membuktikan bahawa responden terbahagi kepada tiga strata mengikut tahap keupayaan.

\section{Kesimpulan}

Pembangunan instrumen perlu dilakukan dengan tepat dan betul dari aspek kesahan dan kebolehpercayaan bagi memastikan instrumen yang dibangunkan dapat digunakan berulang kali. Instrumen yang telah dibina dengan betul pasti tidak akan menghadapi masalah dalam mengukur pembolehubah yang dikaji (Azrilah et al., 2015). Senario ini pastinya akan membantu pengkaji untuk mmbuat keputusan daripada analisis dapatan tersebut. Tambahan lagi, dapatan ini memberi sandaran kepada pengkaji lain agar analisis Rasch terhadap instrumen UPSK dapat dilakukan bagi pelajar di kawasan-kawasan lain. Tuntasnya, analisis kesahan dan kebolehpercayaan menggunakan Model Pengukuran Rasch berjaya menunjukkan bahawa instrumen UPSK adalah sah dan boleh dipercayai untuk mengukur pemikiran sains keusahawanan pelajar Tahun Lima di sekolah rendah di Sabah. 


\section{Rujukan}

Afriana, J., Permanasari, A., \& Fitriani, A. (2016). Project based learning integrated to stem to enhance elementary school's students scientific literacy. Jurnal Pendidikan IPA Indonesia. https://doi.org/10.15294/jpii.v5i2.5493

Antonites, A., \& Vuuren, J. Van. (2005). Inducing entrepreneurial creativity, innovation and oppurtinity-finding skills. South African Journal of Economic and Management Sciences (SAJEMS), 8(3), 255-271.

Aziz, A. A., Jusoh, M. S., Omar, A. R., Amlus, M. H., \& Salleh, T. S. A. (2014). Construct validity: A Rasch measurement model approaches. Journal of Applied Science and Agriculture, 9(12), 7-12.

Azrilah, A. A., Mohd Saidfudin, M., \& Azami, Z. (2015). Asas model pengukuran Rasch: Pembentukan skala \& struktur pengukuran. Penerbit UKM.

Bacigalupo, M., Kampylis, P., Punie, Y., \& Van den Brande, G. (2016). EntreComp: The Entrepreneurship Competence Framework. In Publications Office of the European Union. Publications Office of the European Union. https://doi.org/10.2791/593884

Bahagian Pembangunan Kurikulum. (2014). Dokumen Standard Kurikulum dan Pentaksiran Sains Tahun Lima. Kementerian Pendidikan Malaysia.

Bond, T G, \& Fox, C. M. (2007). Applying the Rasch model. Fundamental measurement in the Human science. New Jersey: Lawrence Earlbaum Associates. Inc. Publicers.

Bond, Trevor G., \& Fox, C. M. (2015). Applying the Rasch Model: Fundamental measurement in the Human Sciences. Routledge. https://doi.org/10.1017/CBO9781107415324.004

Boone, W. J., \& Scantlebury, K. (2005). The role of rasch analysis when conducting science education research utilizing multiple-choice tests. Science Education, 90(2), 253-269. https://doi.org/10.1002/sce.20106

Boone, W. J., Yale, M. S., \& Staver, J. R. (2014). Rasch analysis in the human sciences. Dalam Rasch Analysis in the Human Sciences. Springer. https://doi.org/10.1007/978-94-007-6857-4

Bybee, R. W. (2013). The case for STEM education: Challenges and opportunities. NSTA press.

Chen, A. H., Bakar, N. F. A., \& Lam, C. S. Y. (2020). Comparison of open-ended and close-ended questions to determine signs and symptoms of eye problems among children. Journal of Optometry, 13(2), 81-87. https://doi.org/10.1016/j.optom.2019.07.002

Clarke, J. S., \& Holt, R. (2019). Images of entrepreneurship: Using drawing to explore entrepreneurial experience. Journal of Business Venturing Insights, 11(May), e00129. https://doi.org/10.1016/j.jbvi.2019.e00129

Committee on STEM Education. (2018). Charting a Course for Success: America's Strategy for STEM Education. In National Science and Technology Council.

Creswell, J. W., \& Creswell, J. D. (2017). Research design: Qualitative, quantitative, and mixed methods approaches. Sage publications.

Dabney, K. P., Tai, R. H., Almarode, J. T., Miller-Friedmann, J. L., Sonnert, G., Sadler, P. M., \& Hazari, Z. (2012). Out-of-School time science activities and their association with career interest in STEM. International Journal of Science Education, Part B: Communication and Public Engagement. https://doi.org/10.1080/21548455.2011.629455

Deane, T., Nomme, K., Jeffery, E., Pollock, C., \& Birol, G. (2016). Development of the statistical reasoning in biology concept inventory (SRBCI). CBE Life Sciences Education, 15(1), 1-13. https://doi.org/10.1187/cbe.15-06-0131

Department for Children Schools and Families. (2010). A guide to Enterprise Education.

Deveci, I., \& Cepni, S. (2017). The Effect of Entrepreneurship Education Modules Integrated With Science Education on the Entrepreneurial Characteristics of Pre-Service Science Teachers. Socialinis Darbas, 15(2), 56-85. https://doi.org/10.13165/SD-17-15-2-04

Edwards-Schachter, M., García-Granero, A., Sánchez-Barrioluengo, M., Quesada-Pineda, H., \& Amara, N. (2015). Disentangling competences: Interrelationships on creativity, innovation and entrepreneurship. Thinking Skills and Creativity. https://doi.org/10.1016/j.tsc.2014.11.006

Edwards, A., \& Alcock, A. (2010). Using rasch analysis to identify uncharacteristic responses to undergraduate assessments. Teaching Mathematics and Its Applications, 29(4), 165-175. https://doi.org/10.1093/teamat/hrq008

English, L. D. (2017). Advancing elementary and middle school STEM education. International Journal of Science and Mathematics Education, 15(1), 5-24. https://doi.org/10.1007/s10763-017- 
9802-x

European Commission. (2011). Entrepreneurship education: Enabling teachers as a critical success factor. A report on teacher education and training to prepare teachers for the challenge of entrepreneurship education.

Ho, H.C., Wang, C.C., \& Cheng, Y.Y. (2013). Analysis of the scientific imagination process. Thinking Skills and Creativity, 10, 68-78.

Hoachlander, G., \& Yanofsky, D. (2011). Making STEM real. Educational Leadership, 60-65.

Jin, G., \& Bierma, T. (2013). STEM for non-STEM Majors: Enhancing Science Literacy in Large Classes. Journal of College Science Teaching. https://doi.org/10.2505/4/jcst13_042_06_20

Katz, L. G. (2010). STEM in the Early Years Some Distinctions between Academic and Intellectual Goals for Young. Early Childhood Research and Practice, Collected Papers from the SEED (STEM in Early Education and Development) Conference, 2-7.

Kelley, T. R., \& Knowles, J. G. (2016). A conceptual framework for integrated STEM education. International Journal of STEM Education, 3(1). https://doi.org/10.1186/s40594-016-0046-z

Kementerian Pendidikan Malaysia. (2013). Pelan Pembangunan Pendidikan Malaysia 2013 - 2025. In Kementerian Pendidikan Malaysia (Vol. 27, Issue 1). Kementerian Pendidikan Malaysia.

Kennedy, T. J., \& Odell, M. R. L. (2014). Engaging Students In STEM Education. Science Education International, 25(3), 246-258.

Kline, T. J. B. (2005). Psychological testing: A practical approach to design and evaluation. Sage Publications.

Klooster, P. M. Ten, Taal, E., \& Van De Laar, M. A. F. J. (2008). Rasch analysis of the dutch health assessment questionnaire disability index and the health assessment questionnaire II in patients with rheumatoid arthritis. Arthritis Care and Research, 59(12), 1721-1728. https://doi.org/10.1002/art.24065

Koehler, C., Binns, I. C., \& Bloom, M. A. (2015). The Emergence of STEM. In STEM Road Map: A Framework for Integrated STEM Education. https://doi.org/10.4324/9781315753157-2

Krueger, N. F. (2005). The Cognitive Psychology of Entrepreneurship. Dalam Handbook of Entrepreneurship Research (Issue January, pp. 105-140). Kluster Law International. https://doi.org/10.1007/0-387-24519-7_6

Krueger, N. F. (2007). What lies beneath ? The experiential essence of entrepreneurial thinking. Dalam Entrepreneurship Theory and Practice (Issue 208, pp. 123-139).

Kuenzi, J. J. (2011). Science, technology, engineering, and mathematics (STEM) education: Background, federal policy, and legislative action. Dalam U.S. Science, Technology, Engineering and Mathematics (STEM) Education.

Kuratko, D. F. (2005). The emergence of Entrepreneurship Education: Developmnet, trends and challenges. Dalam Entrepreneurship Theory and Practice (pp. 577-598). Blackwell Publishing Limited.

Lamoureux, E. L., Pesudovs, K., Pallant, J. F., Rees, G., Hassell, J. B., Caudle, L. E., \& Keeffe, J. E. (2008). An evaluation of the 10-item Vision Core Measure 1 (VCM1) scale (the core module of the vision-related quality of life scale) using Rasch analysis. Ophthalmic Epidemiology, 15(4), 224-233. https://doi.org/10.1080/09286580802256559

Lekashvili, E. (2013). Entrepreneurial way of thinking and its development challenges in Georgia. LAssociation 1901 "SEPIKE," 121.

Linacre, J. M. (2002). Understanding Rasch measurement: Optimizing Rating Scale Category Effectiveness. Journal of Applied Measurement, 3, 85-106.

Linacre, J. M. (2003). Dimensionality: contrasts and variances help for Winsteps Rasch Measurement software. Daripada http://www.winsteps.com/winman/principalcomponents.htm.

Liu, X., \& Zhi, T. (2010). China is catching up in science and innovation: The experience of the Chinese Academy of Sciences. Science and Public Policy, 37(5), 331-342. https://doi.org/10.3152/030234210X501162

McDonald, C. (2016). STEM Education: A review of the contribution of the disciplines of Science, Technology, Engineering and Mathematics. Science Education International, 27(4), 530-569.

Menzies, M. B. (2012). Researching scientific entrepreneurship in New Zealand. Science and Public Policy, 39(1), 39-59. https://doi.org/10.3152/030234212X13214603531842

Muhammad Syukri, Lilia Halim, T. Subahan Mohd. Meerah, N. A. B. (2013). Pengetahuan Pedagogi Isi Kandungan Guru Sains Sekolah Rendah dalam Mengajarkan Pemikiran Sains Keusahawanan: 
Satu Kajian Kes. Jurnal Teknologi, 63:2(2013), 13-19.

Muhammad Syukri, Lilia Halim, \& T. Subahan Mohd. Meerah. (2013). Pendidikan STEM dalam Entrepreneurial Science Thinking "ESciT": Satu perkongsian pengalaman dari UKM untuk Aceh. Aceh Development International Conference 2013, 105-112.

National Research Council. (2011). Successful K-12 STEM Education: Identifying Effective Approaches in Science, Technology, Engineering, and Mathematics. National Academies Press.

Nevin, E., Behan, A., Duffy, G., Farrell, S., Harding, R., Howard, R., MacRaighne, A., \& Bowe, B. (2015). Assessing the validity and reliability of dichotomous test results using item response theory on a group of first year engineering students. 6th Research in Engineering Education Symposium: Translating Research into Practice, REES 2015, Rees.

Nor Aishah Buang, Lilia Halim, T. Subahan Mohd. Meerah, Nor Aishah, B., Lilia, H., \& T Subahan, M. M. (2009). Understanding the thinking of scientists entrepreneurs: Implications for science education in Malaysia. Journal of Turkish Science Education, 6(2), 3-11.

Saavedra, A. R., \& Opfer, V. D. (2012). Learning 21st-century skills requires 21 st-century teaching. Phi Delta Kappan, 94(2), 8-13. https://doi.org/10.1177/003172171209400203

Sadler, P. M., Sonnert, G., Hazari, Z., \& Tai, R. (2012). Stability and volatility of STEM career interest in high school: A gender study. Science Education, 96(3), 411-427. https://doi.org/10.1002/sce.21007

Schleicher, A. (2019). PISA 2018: insights and interpretations. In OECD. https://www.oecd.org/pisa/PISA 2018 Insights and Interpretations FINAL PDF.pdf

Schuetz, C. G. (2008). Using neuroimaging to predict relapse to smoking: role of possible moderators and mediators. International Journal of Methods in Psychiatric Research, 17 Suppl 1(March), S78-S82. https://doi.org/10.1002/mpr

Shea, T. L., Tennant, A., \& Pallant, J. F. (2009). Rasch model analysis of the Depression, Anxiety and Stress Scales (DASS). BMC Psychiatry, 9, 1-10. https://doi.org/10.1186/1471-244X-9-21

Shepherd, D. A., Williams, T. A., \& Patzelt, H. (2015). Thinking About Entrepreneurial Decision Making: Review and Research Agenda. Journal of Management, 41(1), 11-46. https://doi.org/10.1177/0149206314541153

Sumintono, B., \& Widhiarso, W. (2015). Aplikasi pemodelan RASCH pada assessment pendidikan (Issue September). Penerbit Trim Komunikata.

Tseng, K.-H., Chang, C.-C., Lou, S.-J., \& Chen, W.-P. (2013). Attitudes towards science, technology, engineering and mathematics (STEM) in a project-based learning (PjBL) environment. International Journal of Technology and Design Education, 23(1), 87-102.

Tsupros, N., Kohler, R., \& Hallinen, J. (2009). STEM education: A project to identify the missing components. Intermediate Unit 1 and Carnegie Mellon.

Venuvinod, P. K., \& Sun, H. (2002). Technological product innovation: An educational perspective from Hong Kong. 9th Asia Pacific Conference of Engineering Management Educators.

Von Kortzfleisch, H. F. O., Zerwas, D., \& Mokanis, I. (2013). Potentials of Entrepreneurial Design Thinking ${ }^{\circledR}$ for Entrepreneurship Education. Procedia - Social and Behavioral Sciences. https://doi.org/10.1016/j.sbspro.2013.12.237

Waugh, R. (2012). Applications of rasch measurement in education. In Applications of Rasch Measurement in Education.

Wolins, L., Wright, B. D., \& Rasch, G. (1982). Probabilistic Models for some Intelligence and Attainment Tests. Journal of the American Statistical Association. https://doi.org/10.2307/2287805

Wyss, V. L., Heulskamp, D., \& Siebert, C. J. (2012). Increasing middle school student interest in STEM careers with videos of scientists. International Journal of Environmental and Science Education.

Zollman, A. (2012). Learning for STEM literacy: STEM literacy for learning. School Science and Mathematics, 112(1), 12-19. https://doi.org/10.1111/j.1949-8594.2012.00101.x

Zulfaka Ishak, Buang, N. A., \& Halim, L. (2014). Ciri-ciri dan tahap Pemikiran Sains Keusahawanan: Kesediaan integrasi Pemikiran Keusahawanan dalam proses pengajaran guru-guru sains Di MRSM. Jurnal Kepimpinan Pendidikan, 1(1), 53-64. 